\title{
Quality of Work Life: A Study on Civil Construction Workers
}

\author{
Gladis Camarini ${ }^{1}$, José Agnaldo Pereira Leite Júnior ${ }^{2}$, Javier Fiz Perez ${ }^{3}$ \& Edna M. Q. O. Chamon ${ }^{4}$ \\ ${ }^{1}$ University Center of Minas South - UNIS-MG, Varginha, Minas Gerais, Brazil; School of Civil Engineering, \\ Architecture and Urban Design, University of Campinas, Campinas, Brazil \\ ${ }^{2}$ National Institute for Space Research - INPE, São José dos Campos, São Paulo, Brazil \\ ${ }^{3}$ European University of Rome, Rome, Italy \\ ${ }^{4}$ Universidade Estácio de Sá - UNESA-RJ, Rio de Janeiro, Brazil \\ Correspondence: Gladis Camarini, University Center of Minas South - UNIS-MG, Varginha, Minas Gerais, Brazil; \\ School of Civil Engineering, Architecture and Urban Design, University of Campinas, Campinas, Brazil
}

Received: April 20, 2020

doi:10.11114/ijsss.v8i4.4820
Accepted: May 26, $2020 \quad$ Available online: June 3, 2020

URL: https://doi.org/10.11114/ijsss.v8i4.4820

\begin{abstract}
The civil construction sector has experienced ongoing changes due to the economic globalization, new technologies, and competition. It demands a large number of workers that are often recruited outside their original city, far from their families, with low work conditions, and without guarantee of continuity in employment, which may affect their health and performance. This study presents an exploratory and descriptive study with a quantitative approach, conducted by the Job Diagnostic Survey (JDS), with 159 workers in the civil construction sector in Brazil. The objective is to assess the level of satisfaction with work, compare the results of different workers at the workplace, and contribute to the discussion about QWL. It was found that the variable General Satisfaction with Work obtained the most negative general average score among the personal and the professional results, pointing out little satisfaction with their work as a whole, which can be improved through training and increase workers empowerment. This study carried out a survey with the construction worker, subjects who are hardly evaluated in research on working conditions. The JDS questionnaire was an important tool in this evaluation, contributing to understanding the variables that impact on the performance of these workers. In this context, improving the quality of work life (QWL) make it possible to assist managers to help workers' satisfaction at work.
\end{abstract}

Keywords: civil construction, job diagnostic survey, quality of work life

\section{Introduction}

The civil construction sector has a significant participation in the Brazilian economy and represents, since the year 2000, a percentage of around 5\% in the country's Gross Domestic Product (GDP). The 2016 Annual Survey of the Construction Industry, conducted by the Brazilian Institute of Geography and Statistics - IBGE (IBGE, 2016), shows that, in that year, the sector corresponded to $5.1 \%$ of the GDP, with total gross revenue of approximately USD 80 billion, and employed 2.01 million workers, with total annual expense with personnel of USD 21.6 billion.

In addition to direct jobs, the civil construction sector generates indirect jobs; however, it presents unfavorable aspects such as: instability (it depends on the country's economic situation), a large number of unregistered workers (which are not considered for official statistics), high turnover and absenteeism rates (Camarini \& Chamon, 2011).

Though the civil construction sector requires a large amount of labor, its employees at the operational level in general have low education and qualification, in addition to belonging to the poorest strata of society. The worksite is still a model of craft production, with little use of machinery, the execution of the services mainly relies on of physical effort and there are high rates of accidents at work (Gramkow, 1999). A large part of the activities is outsourced and harms the workers because it is a discriminatory management practice that promotes poor working conditions, intensifies the alienation and human devaluation; it also facilitates the labor inspection infringement, reduces wages and contributes to the increase of life and health risks (Antunes \& Drucker, 2013).

After the economic globalization and the consequent increase in competition, the sector has gone through great transformations, and seeks to update itself in order to reduce costs, improve the quality of its products and, thus, achieve 
better results. Doing so requires continuous efforts by the sector workers for professionalizing and updating themselves.

In this context, it should be noted the urgent need to improve working conditions in the civil construction sector. Therefore, QWL management is able to provide the development of an environment favorable to meeting workers' needs and to their development.

This study aims to evaluate the level of satisfaction with work, to compare the results of foremen, professional workers, servants and other workers in the sector, as well as to contribute to the discussion on QWL in the segment, which requires more detailed studies on the theme.

\section{Quality of Work Life}

Since the beginning of its existence, man has sought ways to facilitate, bring satisfaction and well-being in the execution of tasks; however, work conditions and their influences on production and the morale of the worker only came to be studied in a scientific way from the 18th century, when the division of tasks, the specialization of steps, the systematization of production methods, the use of specialized tools and equipment, the combination of all production stages into a single location, and the submission of goods to a quality control began to be implemented (Rodrigues, 2014). Thus, a great change in industrial processes and in technological improvement took place. On the other hand, the basic needs of workers were not taken into consideration because they lived in inhuman conditions, with insufficient wages for subsistence and working days of up to 18 hours per day (Rodrigues, 2014).

Elements such as better working methods, better use and specialization of labor, physical improvement of the workplace, among others, have continued to be studied and developed; however, always aimed at increasing productivity and improving quality (Tolfo \& Piccinini, 2011).

Though there were already some studies and experiments related to behavior and human needs at work, the expression Quality of Work Life - QWL only appeared at the beginning of the 1950's, in England. In this opportunity, under the coordination of Trist and Emery, studies on the organization of work were developed. They were based on the socio-technical approach - which considers the social relations in organizations, the organizational conditions of work, and technical conditions to perform the tasks. These studies considered the worker satisfaction at and with their work (Sant'Anna, Kilimnik \& Moraes, 2011).

In September 1972, Richard Walton (1973) used the contributions of theories of human development, such as Maslow's Hierarchy of Needs theory, and presented his work by establishing a model for analysis of experiments under the organizational perspective, which served as the basis for several other studies. Thus, QWL refers to human and environmental values that industrial societies neglect in favor of technology development, productivity, and economic growth. It introduces eight conceptual categories and their respective criteria, related to aspects of physical and mental health, integration, and social development (Walton, 1973):

- Fair and adequate compensation: Internal and external equity, fair compensation, sharing productivity earnings, and proportionality of salaries.

- Safe and healthy working conditions: reasonable working times, safe and healthy physical environment, and absence of insalubrity.

- The opportunity to use and develop human capabilities: autonomy, relative self-control, multiple qualities, information on the whole work process.

- Opportunity for continued growth and employment assurance: possibility of career, personal growth, perspective of advancing wages and job security.

- Social integration into the organization: equality, mobility, relationship, sense of community and absence of prejudices.

- Constitutionalism in the organization: rights of worker protection, personal privacy, freedom of speech, fair treatment, and labor rights.

- Work and the total space in an individual's life: balanced role at work, stability of schedules, few geographical changes and time for leisure activities with the family.

- Social relevance of work: image of the company, corporate social responsibility, liability for products and employment practices.

During the 1960's until beginning of the 1970's there was great development in QWL studies provided by the increased awareness of workers and the social responsibility of companies, leading them to focus their efforts on internal studies on the organization and ways to accomplish the work (Rodrigues, 2014).

It was at that time that Hackman and Oldham (1975), based on measurement methodologies previously developed by 
Turner and Lawrence (1965), and Hackman and Lawler (1971), developed and instrumented the Job Diagnostic Survey (JDS) model, whose approach can be found in Table 1.

Table 1. Job Diagnostic Survey (JDS) Model

\begin{tabular}{|c|c|c|c|c|}
\hline $\begin{array}{c}\text { BASIC } \\
\text { DIMENSIONS OF } \\
\text { THE TASK } \\
\end{array}$ & $\begin{array}{c}\text { CRITICAL } \\
\text { PSYCHOLOGICAL } \\
\text { STATES } \\
\end{array}$ & \multicolumn{3}{|c|}{ PERSONAL AND PROFESSIONAL RESULTS } \\
\hline Variety of Skills & \multicolumn{4}{|c|}{ General Satisfaction with Work } \\
\hline $\begin{array}{l}\text { Identity with the } \\
\text { Task }\end{array}$ & \multirow{3}{*}{$\begin{array}{l}\text { Perception of Work } \\
\text { Significance }\end{array}$} & \multicolumn{2}{|c|}{ Inner Motivation to Work } & \multirow{2}{*}{$\begin{array}{l}\text { Inner Motivation to } \\
\text { Work }\end{array}$} \\
\hline Task Significance & & & $\begin{array}{l}\text { Satisfaction with the } \\
\text { Possibility of Growth }\end{array}$ & \\
\hline Interrelationships & & & $\begin{array}{c}\text { Satisfaction with Safety at } \\
\text { Work }\end{array}$ & $\begin{array}{l}\text { Quality in Work } \\
\text { Performance }\end{array}$ \\
\hline Autonomy & $\begin{array}{c}\text { Perception of } \\
\text { Responsibility for } \\
\text { Results }\end{array}$ & Specific Satisfactions & $\begin{array}{l}\text { Satisfaction with the } \\
\text { Compensation }\end{array}$ & Satisfaction with Work \\
\hline Intrinsic Feedback & Knowledge of the & & $\begin{array}{l}\text { Satisfaction with the } \\
\text { Social Environment }\end{array}$ & \multirow[t]{2}{*}{$\begin{array}{l}\text { Low Turnover and } \\
\text { Absenteeism }\end{array}$} \\
\hline Extrinsic Feedback & Actual Results of Work & & $\begin{array}{l}\text { Satisfaction with the } \\
\text { Supervision }\end{array}$ & \\
\hline \multicolumn{5}{|c|}{ INDIVIDUAL NEED FOR GROWTH } \\
\hline
\end{tabular}

They identified three Critical Psychological States that determine an individual's motivation and satisfaction at work: Perception of Work Significance, Perception of Responsibility for Work Results and Knowledge of Actual Results of Work. Subsequently, they found that the more these psychological states are present in workers, the more they will be internally motivated for the job. After that, they concluded that the Critical Psychological States can only be created by Basic Dimensions of the Task and, as a result, Personal and Professional Results are obtained (Moraes \& Kilimnik, 1989).

The Personal and Professional Results were incorporated into the model in order to identify the emotional or sentimental reactions that a person would have by performing their work (Hackman \& Oldham, 1975), and they encompass the General Satisfaction with Work, the Inner Motivation to Work, and the Specific Satisfactions: Satisfaction with the Possibility of Growth, Satisfaction with Safety at Work, Satisfaction with Compensation, Satisfaction with the Social Environment, and Satisfaction with Supervision.

Hackman and Oldham (2010) also consider the Individual Need for Growth, which is defined as the necessity the worker has to develop actions and ideas, and to have a stimulating and challenging work, which would enable them to be creative, learn new things and feel accomplished. It is through the Individual Needs for Growth that it can be possible to verify the individual differences and the reflexes in the dimensions related to the task.

In short, the objective characteristics of work lead to perceived characteristics that result in attitudes and behaviors such as high inner motivation to work, high quality of performance, high satisfaction with work or high levels of absenteeism and turnover (Hackman \& Oldham, 1975).

The Basic Dimensions of the Task are: Variety of Skills, Identity with the Task, Task Significance, Interrelationships, Autonomy, Intrinsic Feedback and Extrinsic Feedback. The dimensions Variety of Skills, Identity with the Task, Task Significance, Autonomy and Intrinsic Feedback are considered as Essential Dimensions of work, and through them it is possible to determine the Motivational Potential of Work, indicating to which extent the worker recognizes his or her work as significant, and to which extent it provides responsibilities and promotes knowledge of its results (Hackman \& Oldham, 1975). When the workers experience these Essential Dimensions at work, they tend to get a high level of personal satisfaction at work and, as a result, motivation to work (Pedroso, Pilatti, Santos, \& Santos Junior, 2010).

Therefore, QWL, which was previously understood as a single reaction to work, evolved and came to be understood as a way of enriching the work environment, of improving the levels of productivity and workers' satisfaction (Sant'Anna, Kilimnik \& Moraes, 2011).

Current studies on QWL emphasize, mainly, the worker's well-being and satisfaction, valuing workers' participation in the decision-making process, and the humanistic perspective of thinking about people, work, and organization. It is true that, currently, companies need to be increasingly competitive and, therefore, to care about the people, as it is through 
their commitment with the organization's proposals that the results will be achieved successfully (Tolfo \& Piccinini, 2011).

Clegg and Spencer (2007) mention some previous studies of the model of work that have been incorporated to Hackman and Oldham's model: Context of Satisfaction (Oldham, 1996); Management Style (Parker, Wall \& Cordery, 2001); Cognitive Demands (Parker \& Wall, 2001); Proactive Behavior; (Parker \& Turner, 2002); and Contingencies that influence the applicability of the theory, such as Uncertainty (Wall, Cordery \& Clegg, 2002).

These studies incorporated into Hackman and Oldham's (1975) model represent a substantial progress. However, the traditional theory on concepts of work continues to be valid in its essence, and the model of Basic Dimensions of the Task continues to be considered the dominant perspective on the work design theory (Clegg \& Spencer, 2007).

Thus, JDS is considered appropriate for assessing QWL, and this is why it is used in this study for surveying QWL in the civil construction sector.

\section{Method}

\subsection{Work Delimitation}

It is an exploratory and descriptive research, with a quantitative approach performed with workers in the civil construction sector of 3 companies in the southeastern region of Brazil, from the subsector of conventional and non-industrialized buildings, with headquarters in the cities of Campinas, Caçapava and São José dos Campos, State of São Paulo, and works in these same cities, in addition to the city of Rio de Janeiro.

\subsection{Sample}

The invitation was sent to 14 companies, three of them agreed to participate in the research; their workers were also invited to participate. 159 workers from different professional categories were consulted.

It is a convenience sample, as participants were not randomly selected, but by availability to participate in the research. Even so, the survey results provide important conclusions, bearing in mind the limited number of studies of this nature in the construction industry. The results, even if they are not generalized from a statistical point of view, suggest relevant dimensions in the QWL for this area and new directions for research.

\subsection{Questionnaire}

The questionnaire adopted for this research was the Job Diagnostic Survey (JDS), developed by Hackman and Oldham (1975). It is considered appropriate for QWL assessment in several sectors and has been validated by several studies in Brazil and abroad.

The analysis of fidelity was performed by Fernandes \& Becker (1988), who used Cronbach's alpha coefficient and obtained satisfactory results that ensure the internal validity of the scale.

The JDS is composed of 78 questions, with answers presented in a Likert's scale of 1 to 7 points, with the following ranges of score: From 1 to 4 - unsatisfactory; Between 4.01 and 5.99 - satisfactory; Between 6 and 7 - very satisfactory.

In the calculation of the variable Individual Need for Growth, the scale ranges from 4 to 10 points: From 4 to 7 - small; From 7.01 to 8.99 - high; and Between 9 and 10 - very high.

In order to calculate the Motivational Potential of Work, we use the Equation 1, where different weights are attributed to the essential dimensions of the work, Variety of Skills, Identity with the Task, Task Significance, Autonomy and Intrinsic Feedback (Hackman \& Oldham, 1975).

$$
M P W=((V S+I T+T S) / 3) x A U x I F
$$

Where: MPW = Motivational Potential of Work, VS= Variety of Skills, IT $=$ Identity with the Task, TS $=$ Task Significance, $\mathrm{AU}=$ Autonomy, and IF = Intrinsic Feedback

The Motivational Potential of Work has been validated by several studies in Brazil and abroad, and more recently by Pedroso et al. (2010). The maximum score of the MPW category is 343 points, and the minimum is 1 . For scores from 125 points the results are considered satisfactory, and less than 125 points are considered unsatisfactory.

JDS questions are divided into six sections and are formulated using several formats of scales: intensity, concordance, satisfaction, aspiration, and preference. For each variable, a score is produced by aggregating several relevant questions 
that are shuffled along the questionnaire; some of them are reversed, always looking for independent responses to the several stimuli provided (Sant'Anna, Kilimnik \& Moraes, 2011).

Particularly in the case of this research, we have included a section with 23 questions for surveying demographic data of workers, as the individual characteristics, whether biological, social or economic nature, may interfere with the workers' quality of life (Silva, Saldanha \& Azevedo, 2010). We conducted a pre-test with 10 workers in the civil construction sector, which proved the applicability of the JDS instrument and indicated a good acceptance and adherence by workers in the sector (Leite Júnior, Picchi, Camarini \& Chamon, 2012).

\subsection{Data Collection}

The study is in accordance with the Resolution $n^{\circ}$ 466/2012 CNS/MS and complementary. It has been submitted through the system "Plataforma Brasil", from the Ministry of Health, to the Committee for Ethics in Research University of Campinas, UNICAMP, and obtained a favorable opinion, with approval number 922.842.

For data collection, we requested an authorization from the participating companies. Subsequently, the workers were informed about the justification for the study, its objectives, and procedures, and were invited to participate in the research. Those who wished to participate received two copies of the Free and Informed Consent, which was signed by one of the researchers, along with the questionnaire.

Questions about the research and at the completion of the forms were clarified by the researcher that accompanied and provided guidance and assistance to the participants during the process of filling the questionnaire. After reading, completing, and signing the Free and Informed Consent, and responding to the questionnaire, the workers delivered them separately to the researchers, in order to ensure confidentiality and privacy. One copy of the Free and Informed Consent was handed over to the workers who participated in the study.

Workers in the civil construction sector were receptive, and expressed their will to participate in the study, probably by realizing the possibility of improving working conditions in the sector. Some workers were afraid of signing the Free and Informed Consent, and for this reason they did not answer the questionnaire.

\subsection{Data Analysis}

The socio-demographic and QWL data analysis was performed by the software SPHINX®, which makes it possible to organize the research, enter the questionnaire and the data collected, as well as to structure, arrange the reports in several manners, perform analyses of main components, standard deviation, correspondences, tables of means, and groups table.

In order to verify the variability of the data, we calculated the coefficient of variation $(\mathrm{CV})$, which is the relative standard deviation (SD) divided by the mean. The higher the $\mathrm{CV}$, the greater the data variability in relation to the mean and the lower the $\mathrm{CV}$, the lower the data variability in relation to the mean.

From a statistical point of view, the results are only valid for the studied group. The statistical generalization of the results is hampered, as it is a convenience sample. However, as already indicated, these results may provide directions for further research.

Even though it is not a random sampling of subjects, a comparison test of means for the results of the JDS's variables was performed, seeking to verify the differences between them. Wilcoxon test was used for paired samples, also known as signed rank. It is a non-parametric test, suitable for categorical variables, in which various responses correspond to a single subject in the dimensions of the questionnaire. The test considered all the individuals who compose the sample.

\section{Results and Discussion}

\subsection{Worker Information}

The sample demonstrates heterogeneity in relation to age, schooling, gender, and professional category, enabling a broad analysis on workers in the field.

The sample was composed of 12 (7.55\%) Foremen, 69 (43.39\%) Professionals, 48 (30.19\%) Servants and 30 (18.87\%) Other Workers (Figure 1). It was defined as "Professionals" those workers with specific functions: carpenters, electricians, plumbers, ironworkers, installers, bricklayers, and painters. The category "Other Workers" includes technical assistants, safety-at-work technical assistants, environment technical assistants, appropriators, timekeepers, CAD operators, technicians, assembly technicians, production technicians, planning technicians and work safety-at-work technicians. 


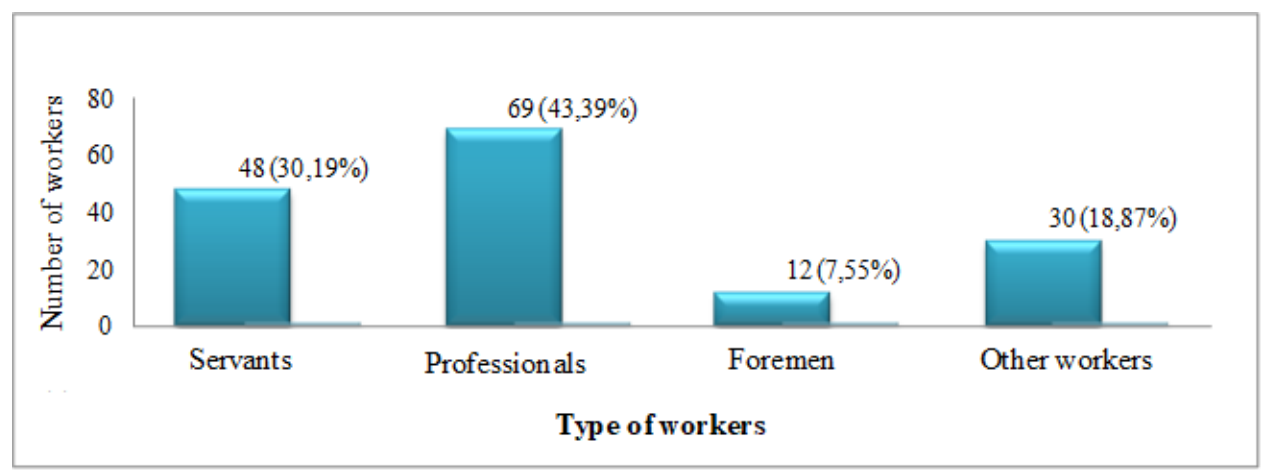

Figure 1. Number of workers in accordance with the category of work

Regarding gender (Figure 2), 145 (91.19\%) workers are male, and 14 (8.81\%) are female. In recent years, the civil construction sector has registered a growing presence of female workers. According to the Annual Relation of Social Information - RAIS, from the Ministry of Labor and Employment - MTE, in 2018 the Brazilian civil construction sector had 286,317 female workers, representing $10.3 \%$ of the labor force in the industry (Câmara Brasileira da Indústria da Construção [CBIC], 2018).

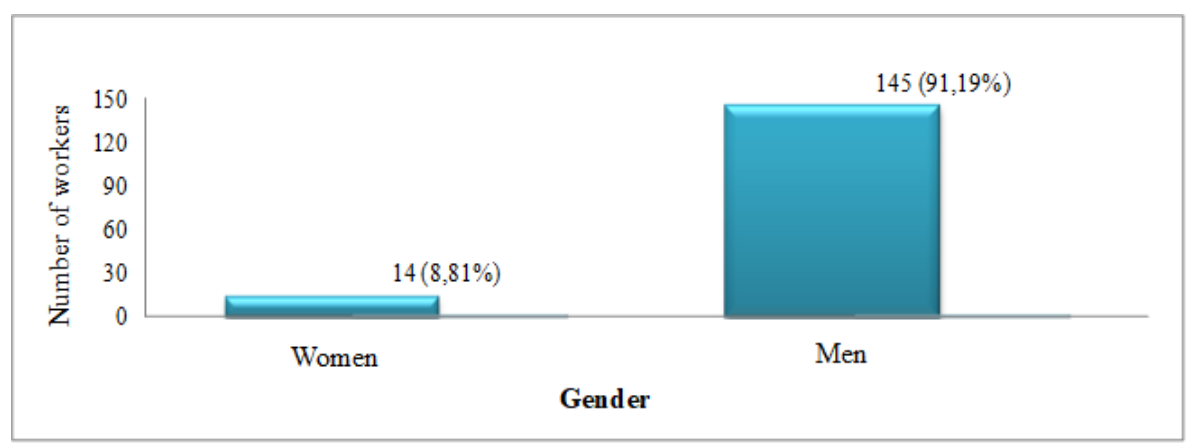

Figure 2. Number of employees based on gender

Workers in the civil construction sector perform intense physical efforts. With the increase of age, fatigue resulting from physical effort carried out in the course of life results in loss of capacity or of physical characteristics that are important for performing their activity, such as: muscle strength, agility, elasticity, dexterity and even balance capacity (Lima, 1995). Perhaps these facts explain why the majority of workers who compose the sample was 35 years old or less $(93$ workers $-58.49 \%$ ), as shown in Figure 3.

With regard to marital status (Figure 4), 54 (33.96\%) workers are single, 85 (53.46\%) married, 15 (9.43\%) divorced or separated, $5(3.15 \%)$ widowed and $2(1.27 \%)$ did not answer. It is possible to notice that many workers are single, perhaps due to the low age of those who are the sample.

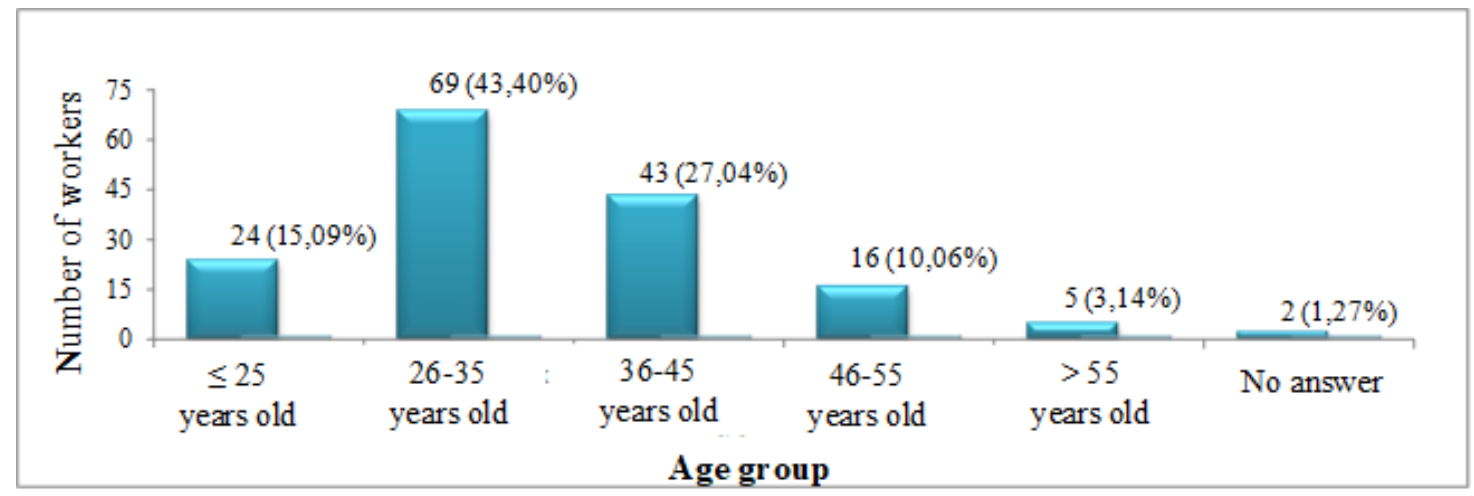

Figure 3. Number of workers, according to age 


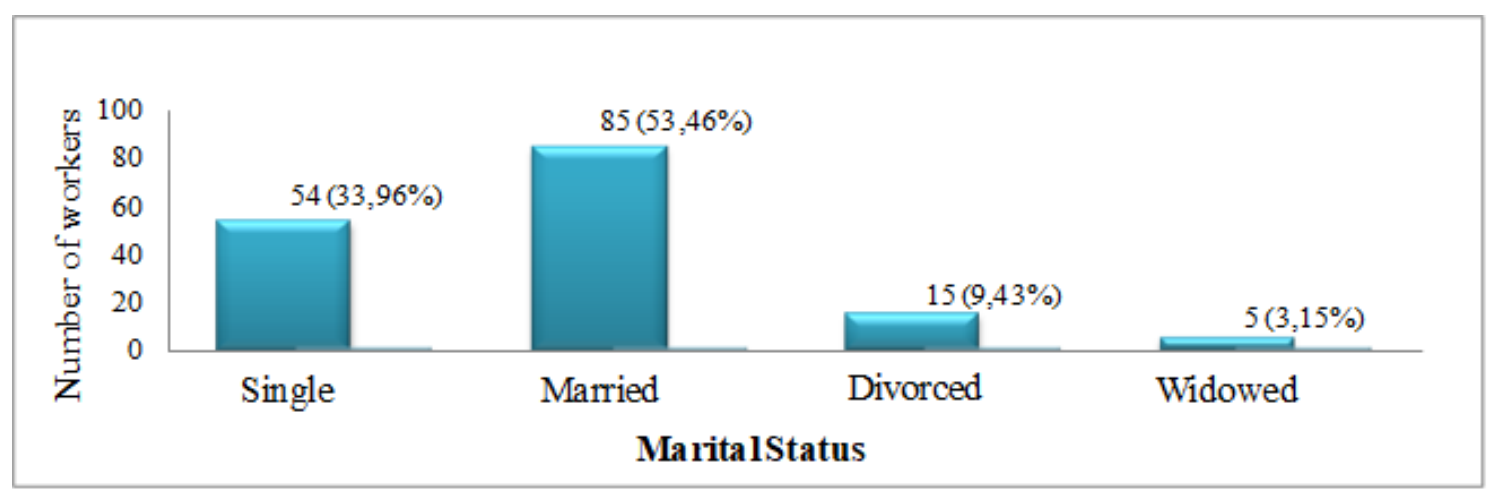

Figure 4. Number of workers based on marital status

In general, workers in the civil construction sector have low schooling, low qualification and belong to the poorest layers of the population (Gramkow, 1999). The results (Table 2) indicated that $40(25.16 \%)$ workers have incomplete basic education, $26(16.35 \%)$ complete basic education, $25(15.72 \%)$ incomplete secondary education or technical course, $43(27.05 \%)$ complete secondary education or technical course, $17(10.69 \%)$ incomplete higher education and 8 $(5.03 \%)$ have complete higher education.

Table 2. Construction Workers based on schooling levels in 2018

\begin{tabular}{ccc}
\hline Schooling & Survey (\%) & Brazil (\%)* \\
\hline Illiterate & - & 0.7 \\
Incomplete basic education & 25.2 & 16.4 \\
Complete basic education & 16.4 & 19.6 \\
\hline Incomplete high school & 15.7 & 8.2 \\
Complete high school & 27.0 & 46.6 \\
\hline Incomplete higher education & 10.7 & 2.2 \\
Complete higher education & 5.0 & 6.3 \\
\hline Total & 100.0 & 100.0 \\
\hline * Source. RAIS 2014 - MTE (CBIC , 2018) & &
\end{tabular}

The results concerning the workers' population schooling levels in the sector in Brazil are not proportionately aligned with data of those who are in the sample (Table 2). The illiterate was not found, the high school incomplete is higher and complete is lower. Higher education complete is lower and incomplete is higher. These results show that this sample has low schooling than found in Brazilian civil construction workers.

\subsection{Local of Work and Labor Contract}

The workers developed their activities in four cities (Figure 5): 19 in Campinas-SP (11.95\%), 25 in Caçapava-SP (15.72\%), 83 in São José dos Campos-SP (52.2\%), 31 in Rio de Janeiro-RJ (19.49\%) and 1 (0.64\%) did not respond.

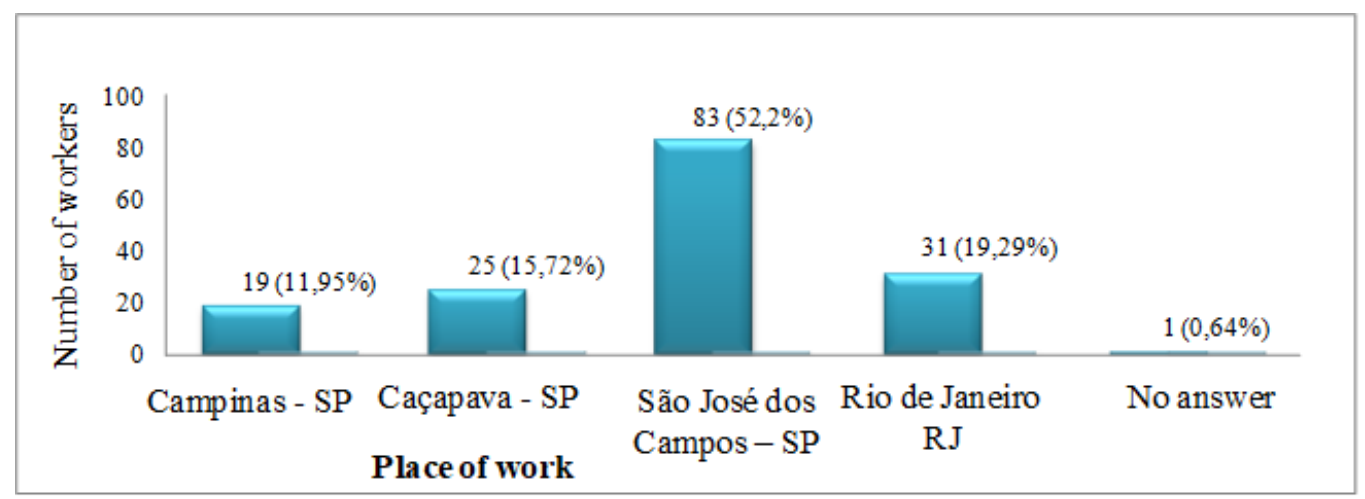

Figure 5. Number of employees based on place of work 
Considering all these workers (Figure 6), 114 (71.69\%) are hired by the construction company, 42 (26.42\%) are outsourced and $3(1.89 \%)$ are autonomous. It should be noted that a large part of the activities is outsourced in the construction industry, and Okoye, Okolie, \& Aderibigbe (2014) observed that the workers' behaviors are influenced by their perceptions and also the work environment, and that outsourced and/or autonomous workers show a high feeling of lethargy with regard to policies and programs of safety of the employers.

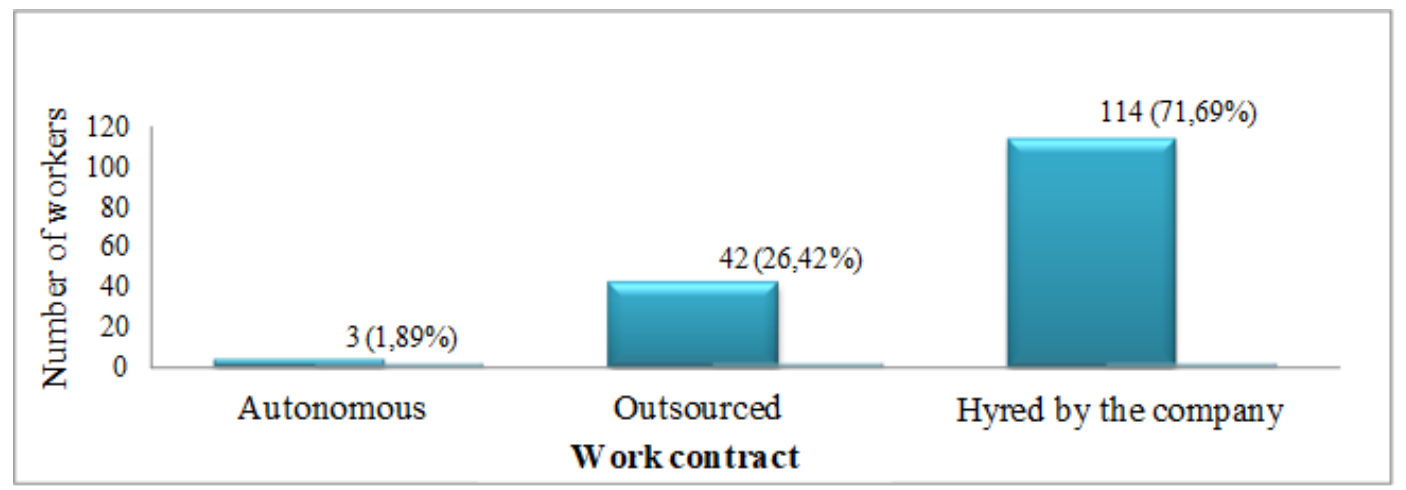

Figure 6. Number of employees based on the type of labor contract

The reduction of costs, ease of resignation and the flexibilization of staff are some of the reasons for the use of outsourced labor in the construction industry. However, this system of employment reveals itself that it is not a good choice, especially when considered in the long term as, in general, there is no safety training, no integration of all workers in a construction site, and as a result, no participation in all the matters that are of their concern. Another problem for the worker is that outsourcing offers no guarantee of continuity in the job, which can be harmful to the worker's health.

\subsection{JDS - Basic Dimensions of the Task}

JDS has made it possible to identify the level of satisfaction with work and the functional aspects that interfere in the QWL of the workers that comprise the sample. It also allowed the comparison of mean scores of the four surveyed professional categories - for the group of workers in the study - whereas data variability in relation to the mean is low, according to the calculated coefficient of variation (CV).

Table 3 presents the average scores for the Basic Dimensions of the Task, which are the characteristics of the work that lead to Critical Psychological States. Workers who provide a good assessment to the Basic Dimensions of the Task are more motivated to work. They tend to have positive responses to tasks, and a great need for growth (Hackman \& Oldham, 2010).

Table 3. Mean for the Basic Dimensions of the Task

\begin{tabular}{|c|c|c|c|c|c|c|c|c|c|c|c|c|c|c|c|}
\hline \multirow{2}{*}{ Variable } & \multicolumn{3}{|c|}{ Foremen } & \multicolumn{3}{|c|}{ Professional } & \multicolumn{3}{|c|}{ Servants } & \multicolumn{3}{|c|}{ Other Workers } & \multicolumn{3}{|c|}{ General } \\
\hline & Mean & SD & $\mathrm{CV}$ & Mean & $\mathrm{SD}$ & $\mathrm{CV}$ & Mean & $\mathrm{SD}$ & $\mathrm{CV}$ & Mean & $\mathrm{SD}$ & $\mathrm{CV}$ & Mean & $\mathrm{SD}$ & $\mathrm{CV}$ \\
\hline Variety of Skills & 5.03 & 0.67 & 0.13 & 4.87 & 0.96 & 0.20 & 5.51 & 0.93 & 0.17 & 4.73 & 1.03 & 0.22 & 4.75 & 0.97 & 0.20 \\
\hline $\begin{array}{c}\text { Identity with the } \\
\text { Task }\end{array}$ & 4.11 & 0.68 & 0.17 & 4.32 & 0.87 & 0.20 & 4.14 & 0.75 & 0.18 & 4.2 & 0.95 & 0.23 & 4.23 & 0.84 & 0.20 \\
\hline Task Significance & 6.17 & 0.71 & 0.12 & 5.63 & 1.12 & 0.20 & 5.15 & 1.16 & 0.23 & 5.81 & 0.86 & 0.15 & 5.56 & 1.11 & 0.20 \\
\hline Interrelationships & 6.06 & 0.93 & 0.15 & 5.35 & 0.84 & 0.16 & 5.17 & 0.68 & 0.13 & 5.47 & 0.97 & 0.18 & 5.35 & 0.91 & 0.17 \\
\hline Autonomy & 4.61 & 1.26 & 0.27 & 4.41 & 1.06 & 0.24 & 4.21 & 0.95 & 0.23 & 4.81 & 1.2 & 0.25 & 4.44 & 1.09 & 0.25 \\
\hline Intrinsic Feedback & 5.56 & 0.82 & 0.15 & 5.71 & 1.02 & 0.18 & 5.38 & 1.04 & 0.19 & 5.49 & 0.76 & 0.14 & 5.56 & 0.98 & 0.18 \\
\hline Extrinsic Feedback & 5.58 & 1.26 & 0.23 & 4.83 & 1.05 & 0.22 & 4.87 & 1.01 & 0.21 & 5.03 & 1.02 & 0.20 & 4.94 & 1.07 & 0.22 \\
\hline
\end{tabular}

With regard to the general mean, it is observed that "Identity with the Task" obtained the lowest results, with a mean score of 4.23 points, and indicative of satisfactory (4.01-5.99), but very close to unsatisfactory (1-4). This variable assesses to which extent the task must be completed as a whole, i.e. whether the job is to be executed from beginning to end, so that the result is clear. The lowest scores were obtained by Foremen (4.11) and Servants (4.14). In the description of the Brazilian Classification of Occupations - CBO by its acronym in Portuguese - (MTE, 2007), Foremen are responsible for the technical documentation, supervising the staff, and controlling the work's productive patterns such as: work's schedule, physical arrangements, inputs, guidance on specifications, workflow and movement 
of material, and safety measures of workplaces and worksite equipment. Servants are responsible for preparing and cleaning the worksites in the first level, such as: demolition, soil compaction, internal transport of inputs, cleaning of machinery and equipment, preparation of concrete mass and other materials (MTE, 2007). In both cases the tasks are varied, with different levels of difficulty, which require identity with several types of activities. These professionals may identify themselves well with some of the tasks, and not with others, which would be a possible reason for the low score.

The "Task Significance", which assesses how the workers realize the importance the task has on life or work of others - i.e. how they perceive the social relevance of their work — had the highest general average score, with 5.56 points (indicative of satisfactory $=4.01-5.99$ ). Foremen were those who provided more positive assessments, with 6.17 points (very satisfactory $=6-7$ ), perhaps because they realize the importance of their work to other workers' life and work, and also to the work's delivery within the project's specifications, which is very important for the other parties involved in the work, and also for the client.

The "Intrinsic Feedback" assesses to which extent the task implementation provides direct and clear information regarding the effectiveness of their performance. It refers to the information received by the worker as a natural consequence of performing an action or task. This category also had the highest general average score, with 5.56 points (indicative of satisfactory $=4.01-5.99$ ). Professionals such as carpenters, electricians, plumbers, ironworkers, installers, bricklayers, painters, among other skilled workers, assessed it more positively (5.71), probably because they can see the results of their work as it are performed; therefore, the quality of the outcomes can be evidenced. The Professionals according to their specific activities - organize and prepare the workplace and the inputs at the worksite, operationalize work or installation projects; they are also required to follow standards of safety, hygiene, quality, and environmental protection (MTE, 2007). They have the ability to control their performance during the execution and perceive the final result.

It is worth noting that the "Interrelationship", which evaluates how employees interact with other people - internally or externally to the work - also obtained a high average general score of 5.35 points, considered satisfactory. Foremen provided the best assessment in this category - 6.06 points — an indication of very satisfactory; perhaps because these professionals are responsible for supervising the team of workers, and need to interact with lots of people such as their line managers, direct reports, suppliers and even clients. This variable is not motivating, as it is extrinsic to the individual and only helps making the environment more pleasant. It also generates well-being; however, if it is not present, it would generate dissatisfaction (Sant'Anna, Kilimnik \& Moraes, 2011).

The categories of "Variety of Skills", "Autonomy" and "Extrinsic Feedback" obtained satisfactory average scores: 4.75, 4.44 and 4.94 points, respectively. These results are not negative but are closer to unsatisfactory (1-4) than to very satisfactory (6-7). These categories should be better investigated, as they assess:

- Variety of Skills: The multiplicity of different activities, skills and talents required from the workers for the execution of their tasks.

- Autonomy: The degree of freedom, independence, and power of decision on planning and executing the task, and it is related to the opportunity to use and develop human capacities.

- Extrinsic Feedback: The amount of clear information the worker receives from line managers and colleagues during and after the task implementation - being considered a tool of great importance for the worker, as it is the feedback they receive on their performance, and it enables them to make the necessary adjustments in order to improve it.

\subsection{JDS - Critical Psychological States}

Table 4 presents the average scores for the" Critical Psychological States" that are generated by the "Basic Dimensions of the Task" (Hackman \& Oldham, 2010). The more they are present on the workers, the more they are internally motivated for the work, and thus, positive Personal and Professional Results are obtained.

The presence of positive psychological states leads the worker to feel satisfied and internally motivated to work, which provides benefits to the company, such as quality at work, assiduity, and low turnover rates. This is not based on extrinsic rewards, but on the work itself, i.e., the workers realize that they are performing a meaningful work, for which they are responsible, and are aware that it was well performed.

The category "Knowledge of Actual Results of Work", that evaluates to which extent workers know the real results of their work when it is performed, obtained the most unfavorable general average (4.77 points), which though it is considered satisfactory, is a low rate. It is possible to note that the most favorable assessment was provided by Foremen, followed by Professionals with 4.97 and 4.83 points, respectively. Foremen, by supervising teams of workers, controlling productive patterns and managing the work schedule, typically perform their work as a whole (MTE, 2007). 
The same is true for Professionals who develop specialized activities that in general are executed from the beginning to the end; therefore, they are able to realize the result of their work in a better way.

The "Perception of Responsibility for Results" generates attitudes and behaviors at work. Workers who do not realize their responsibility for results may have their performance compromised. This was the psychological state with the best evaluation, with an average score of 5.73 points, quite close to very satisfactory. Foremen assessed it as very satisfactory, with 6.06 points, perhaps because they are responsible for supervising teams of workers, controlling productive patterns and managing the work schedule, as already mentioned.

Regarding the "Perception of Work Significance", which assesses to which extent workers considers their work as important, valuable and significant - within its scale of values - also obtained a positive assessment, with an average score of 5.65 points, considered satisfactory and close to very satisfactory. Foremen also assessed it as very satisfactory, with 6.38 points, which is the most favorable score. This evaluation may be related to the enriched and varied activities related to the position of Foremen, as they have several responsibilities.

Table 4. Mean for the Critical Psychological States

\begin{tabular}{|c|c|c|c|c|}
\hline \multicolumn{2}{|c|}{ Variables } & $\begin{array}{l}\text { Perception of Work } \\
\text { significance }\end{array}$ & $\begin{array}{c}\text { Perception of } \\
\text { Responsibility for } \\
\text { Results } \\
\end{array}$ & $\begin{array}{l}\text { Knowledge of the } \\
\text { Actual Results of } \\
\text { Work }\end{array}$ \\
\hline \multirow{3}{*}{ Foremen } & Mean & 6.38 & 6.06 & 4.79 \\
\hline & SD & 0.40 & 0.47 & 0.69 \\
\hline & $\mathrm{CV}$ & 0.06 & 0.07 & 0.14 \\
\hline \multirow{3}{*}{ Professional } & Mean & 5.74 & 5.80 & 4.83 \\
\hline & SD & 0.92 & 0.69 & 0.64 \\
\hline & $\mathrm{CV}$ & 0.16 & 0.12 & 0.13 \\
\hline \multirow{3}{*}{ Servants } & Mean & 5.46 & 5.52 & 4.78 \\
\hline & SD & 0.81 & 0.80 & 0.59 \\
\hline & $\mathrm{CV}$ & 0.15 & 0.14 & 0.12 \\
\hline \multirow{3}{*}{ Other workers } & Mean & 5.46 & 5.77 & 4.57 \\
\hline & SD & 0.91 & 0.58 & 0.63 \\
\hline & $\mathrm{CV}$ & 0.17 & 0.10 & 0.14 \\
\hline \multirow{3}{*}{ General } & Mean & 5.65 & 5.73 & 4.77 \\
\hline & SD & 0.89 & 0.72 & 0.64 \\
\hline & $\mathrm{CV}$ & 0.16 & 0.13 & 0.13 \\
\hline
\end{tabular}

\subsection{JDS - Personal and Professional Results}

Table 5 presents the average scores for Personal and Professional Results, which identify affective or sentimental personal reactions the workers have by performing their work (Sant'Anna, Kilimnik, Moraes, 2011). In the JDS model, Personal and Professional Results are key indicators of QWL (Moraes \& Kilimnik, 1989).

It should be noted that personal and professional results obtained a favorable assessment, and only "General Satisfaction with Work" achieved an average score below 5 points, of 4.94 points. Servants, followed by Other Workers, were those who provided the worst assessment, with 4.59 and 4.50, respectively. This variable shows the worker's level of satisfaction with work. The levels of esteem and satisfaction with work can be improved through greater training for worker (Gilgeous, 1998).

"Satisfaction with Safety at Work", which assesses the level of satisfaction with employment assurance, working hours, and the physical environment (safety, insalubrity, hygiene, among others), and "Satisfaction with the Compensation", which considers fairness in compensation, sharing of productivity gains, proportionality of salaries, internal and external equity, among other aspects related to compensation, had general average scores of 5.02 and 5.05 points, respectively. Foremen assessed them with an average score below 5 points; other Workers evaluated the "Satisfaction with the Compensation" with an average score of 4.73 points; and, Professionals evaluated the Satisfaction with Safety at Work with an average score of 4.99 Points.

It is important to highlight that the category of Other Workers includes technical assistants, technical assistants for safety at work, environment technical assistants, appropriators, time keepers, CAD operators, technicians, assembly technicians, production technicians, planning technicians, and safety-at-work technicians, and $65.63 \%$ of these workers are in the civil construction sector for five years or less; thus, perhaps for this reason they have assessed Satisfaction with the Compensation more negatively. 
Table 5. Mean for Personal and Professional Results

\begin{tabular}{|c|c|c|c|c|c|c|c|c|c|c|c|c|c|c|c|}
\hline \multirow{2}{*}{ Variable } & \multicolumn{3}{|c|}{ Foremen } & \multicolumn{3}{|c|}{ Professionals } & \multicolumn{3}{|c|}{ Servants } & \multicolumn{3}{|c|}{ Other Workers } & \multicolumn{3}{|c|}{ General } \\
\hline & Mean & SD & $\mathrm{CV}$ & Mean & $\mathrm{SD}$ & $\mathrm{CV}$ & Mean & $\mathrm{SD}$ & $\mathrm{CV}$ & Mean & $\mathrm{SD}$ & $\mathrm{CV}$ & Mean & SD & $\mathrm{CV}$ \\
\hline $\begin{array}{c}\text { General Satisfaction with } \\
\text { Work }\end{array}$ & 5.27 & 0.91 & 0.17 & 5.1 & 0.86 & 0.17 & 4.59 & 0.8 & 0.17 & 4.9 & 1.25 & 0.26 & 4.94 & 0.95 & 0.19 \\
\hline Inner Motivation to Work & 5.69 & 0.52 & 0.09 & 5.48 & 0.63 & 0.11 & 5.28 & 0.69 & 0.13 & 5.39 & 0.66 & 0.12 & 5.42 & 0.66 & 0.12 \\
\hline $\begin{array}{l}\text { Satisfaction with the } \\
\text { Possibility of Growth }\end{array}$ & 5.69 & 1.03 & 0.18 & 5.78 & 0.84 & 0.15 & 5.26 & 1.17 & 0.22 & 4.98 & 1.2 & 0.24 & 5.46 & 1.08 & 0.20 \\
\hline $\begin{array}{c}\text { Satisfaction with Safety } \\
\text { at Work }\end{array}$ & 4.46 & 1.96 & 0.44 & 4.99 & 1.55 & 0.31 & 5.08 & 1.55 & 0.31 & 5.22 & 1.1 & 0.21 & 5.02 & 1.52 & 0.30 \\
\hline $\begin{array}{l}\text { Satisfaction with the } \\
\text { Compensation }\end{array}$ & 4.92 & 1.15 & 0.23 & 5.24 & 1.26 & 0.24 & 5.2 & 1.15 & 0.22 & 4.73 & 1.29 & 0.27 & 5.05 & 1.33 & 0.26 \\
\hline $\begin{array}{l}\text { Satisfaction with the } \\
\text { Social Environment }\end{array}$ & 5.92 & 0.67 & 0.11 & 5.98 & 0.73 & 0.12 & 6.14 & 1.27 & 0.21 & 5.7 & 0.8 & 0.14 & 5.86 & 0.82 & 0.14 \\
\hline $\begin{array}{l}\text { Satisfaction with the } \\
\text { Supervision }\end{array}$ & 5.5 & 1.03 & 0.19 & 5.21 & 1.35 & 0.26 & 6.21 & 0.87 & 0.14 & 5.07 & 1.38 & 0.27 & 5.28 & 1.27 & 0.24 \\
\hline
\end{tabular}

The foremen are responsible for technical documentation of the work, for supervising the team of workers, and for controlling productive patterns of work. The Professionals are engaged in specific activities. Perhaps these workers have evaluated Satisfaction with Safety at Work more negatively due to the great responsibility they have at the worksite. It is also observed that $91.67 \%$ of the Foremen and $81.16 \%$ of the Professionals consider that their work has medium or high risk of accidents.

Servants evaluated "Satisfaction with the Social Environment" quite well, which refers to relationships at the work environment, and Satisfaction with the Supervision, which is related to the work's organization. Both are considered by Herzberg (1968) as hygienic factors, which are able to prevent suffering. Satisfaction with the Social Environment is related to social skills and social support, which are considered by Carneiro, Falcone, Del Prette, \& Del Prette (2007) as critical for a good quality of life. In this sense, today several studies have investigated the types of relationships that are beneficial to health, and lots of them conclude that social support brings benefits both to the physical and the mental health, with strictly related to well-being (Resende \& Gouveia, 2011).

The "Inner Motivation to Work", considered a global variable and a strong indicator of QWL, was well assessed and had a general average of 5.42 points, while all other professional categories in the sample assessed it with an average between 5.28 and 5.69 points. For Hackman and Oldham (2010), the workers' motivation is proportional to the extent at which they believe in obtaining positive results. In order to ensure that the results are perceived as positive, it is necessary to relate the satisfaction of individual needs to the achievement of organizational goals and thus, the goals need to be known to all workers.

"Satisfaction with the Possibility of Growth" evaluates the degree of satisfaction and well-being that the worker has in relation to the possibility of growth offered by the job. It should be noted that for Other Workers it had a lower average score, with 4.98 points, probably because $65.63 \%$ of these workers are working in the civil construction sector for five years at most, and six of them are outsourced.

\subsection{JDS - Individual Need for Growth}

The "Individual Need for Growth" evaluates to which extent the workers need to develop themselves, take actions and have ideas; whether they have a stimulating and challenging work, opportunities to be creative, sense of accomplishment and opportunity to learn new things (Sant'Anna, Kilimnik \& Moraes, 2011). This variable had a general average score of 8.16 points, indicating high Individual Need for Growth (7.01-8.99). It is possible to notice that Foremen had a higher average score of 8.49 points, followed by Professionals, with 8.46 points (Table 6 ).

Table 6. Mean for the Individual Need for Growth

\begin{tabular}{|c|c|c|c|c|c|c|c|c|c|c|c|c|c|c|c|}
\hline \multirow{2}{*}{ Variable } & \multicolumn{3}{|c|}{ Foremen } & \multicolumn{3}{|c|}{ Professionals } & \multicolumn{3}{|c|}{ Servants } & \multicolumn{3}{|c|}{ Other Workers } & \multicolumn{3}{|c|}{ General } \\
\hline & Mean & $\mathrm{SD}$ & $\mathrm{CV}$ & Mean & $\mathrm{SD}$ & $\mathrm{CV}$ & Mean & $\mathrm{SD}$ & $\mathrm{CV}$ & Mean & $\mathrm{SD}$ & $\mathrm{CV}$ & Mean & $\mathrm{SD}$ & $\mathrm{CV}$ \\
\hline $\begin{array}{l}\text { Individual } \\
\text { Need for } \\
\text { Growth }\end{array}$ & 8.49 & 1.13 & 0.13 & 8.46 & 1.19 & 0.14 & 7.87 & 1.28 & 0.16 & 7.82 & 1.14 & 0.15 & 8.16 & 1.24 & 0.15 \\
\hline
\end{tabular}

When workers have an increased need for growth, there is a great possibility that they would give a positive response to the task's enrichment, i.e., the tasks that offer more significance, responsibility, and knowledge of results. It is possible 
to notice that the activities developed by Foremen and by Professionals require more technical knowledge, expertise, and training.

This type of work is beneficial for workers who have the necessary skills and promotes strong personal needs for growth and learning. These workers tend to be satisfied with their wages, with colleagues and supervisors (Hackman \& Oldham, 2010).

\subsection{JDS - Motivational Potential of Work}

The "Motivational Potential of Work" indicates to which extent workers recognize that their work is significant, provides accountability and promotes the knowledge of its results (Hackman \& Oldham, 1975). When the workers experience these essential dimensions, they tend to have a high level of personal satisfaction at work and, as a result, motivation (Pedroso et al., 2010). Table 7 indicates that Foremen and Other Workers were the professional categories that had a score above 124.99 points, indicating that there is a Motivational Potential of Work.

Table 7. Mean for the Motivational Potential of Work

\begin{tabular}{cccccc}
\hline Variable & Foremen & Professionals & Servants & Other Workers & General \\
Mean & Mean & 117.09 & 107.71 & 127.89 & 115.80 \\
\hline Motivational Potential of Work & 137.15 & Mean & \\
\hline
\end{tabular}

Professionals and Servants had a score below 125 points, an indication of low motivational potential for work. This result needs to be better investigated through qualitative research.

\subsection{Wilcoxon Tests}

Wilcoxon's test was performed for all possible pairs of variables, and the results demonstrate that, in most cases, the variables means are effectively different with a high level of probability, with $\mathrm{p}$ values lower than $5 \%$, and most of the times, lower than $0.1 \%$.

Essentially, this is an indication that the obtained means would be effectively different if a statistical generalization of the results were made. Even though this generalization is limited by the sample's characteristics, the results show potential ways for deeper investigation.

Table 8 presents the results for variables' means of the Basic Dimensions of the Task. It should be noted that there is no significant difference between the means of variables Task Significance - TS and Intrinsic Feedback - IF.

In the comparison between the means of variables Perception of the Task Significance - PTS and Perception of Responsibility for Results - PRR, it is possible to notice that the level of significance is greater than 5\% (Table 9).

Table 8. Wilcoxon's test for the Basic Dimensions of the Task

\begin{tabular}{cccccccc}
\hline Variable & VS & IT & TS & IR & AU & IF & EF \\
\hline VS & - & $<0.0001$ & $<0.0001$ & $<0.0001$ & 0.0047 & $<0.0001$ & 0.0415 \\
IT & & - & $<0.0001$ & $<0.0001$ & 0.0257 & $<0.0001$ & $<0.0001$ \\
TS & & & - & 0.0299 & $<0.0001$ & 0.9893 & $<0.0001$ \\
IR & & & & - & $<0.0001$ & 0.0372 & $<0.0001$ \\
AU & & & & & - & $<0.0001$ & $<0.0001$ \\
IF & & & & & & - & $<0.0001$ \\
EF & & & & & & & - \\
\hline
\end{tabular}

Table 9. Wilcoxon's Test for Critical Psychological States

\begin{tabular}{cccc}
\hline Variable & PTS & PRR & CRW \\
\hline PTS & - & 0.7942 & $<0.0001$ \\
PRR & & - & $<0.0001$ \\
CRW & & & - \\
\hline
\end{tabular}


In the comparison between the means of variables Personal and Professional Results, it is possible to notice that the significance level is very small in several cases; however, some of the results achieved a significance level greater than

$5 \%$ (Table 10).

Table 10. Wilcoxon's Test for Personal and Professional Results

\begin{tabular}{cccccccc}
\hline Variable & GSW & IMW & SPG & SSW & SC & SSE & SSU \\
\hline GSW & - & $<0.0001$ & $<0.0001$ & 0.1855 & 0.1675 & $<0.0001$ & $<0.0001$ \\
IMW & & - & 0.1279 & 0.1991 & 0.0624 & $<0.0001$ & 0.9230 \\
SPG & & & - & 0.0387 & $<0.0001$ & $<0.0001$ & 0.7034 \\
SSW & & & & - & 0.8982 & $<0.0001$ & 0.0122 \\
SC & & & & & - & $<0.0001$ & 0.0095 \\
SSE & & & & & & & $<0.0001$ \\
SSU & & & & & & & - \\
\hline
\end{tabular}

The results obtained in this case point out to two important conclusions. The first concerns the specific conclusions about the studied group. In this case, the results demonstrate the values for the QWL variables and their order. This information can be used as a diagnostic for the studied group and for QWL management in these companies.

The second conclusion concerns the generalization of these results to other groups within the civil construction sector. In this case, though in a limited way, the results also indicate an order of results, considering that the differences of averages (in most cases) are significant.

\section{Conclusions}

The obtained results show the applicability of the JDS questionnaire for evaluating QWL in the civil construction sector. These results, which are strictly valid for the studied group, represent a QWL diagnostic for the workers, which enables a management work in the companies. Since the sample is obtained by convenience, it is not possible to advance to a statistical generalization; however, the conclusions point to dimensions that should be observed with the utmost care.

Regarding the Basic Dimensions of the Task, the variables Identity with the Task and Autonomy obtained the lowest average scores, indicating that it is necessary to identify problems and correct them. Autonomy provides the worker with greater Identity with the Task. When the worker has freedom, independence, and power of decision over the planning and execution of the task, the identity may arise as a result. The variable Task Significance obtained a higher average score and suggests that workers perceive well the importance that the task in life and/or the work of other people in the internal and external environment.

Considering the Critical Psychological States, the Knowledge of the Actual Results of Work obtained the lowest general average score, and requires further studies, as the more the workers realize that their work is being well executed, the more stimulated they will be to execute it better. The Perception of Responsibility for Results and the Perception of Work Significance obtained higher general average scores. This fact suggests that workers in the industry are aware of the importance, value, and significance of their work, and also of the responsibility they have for the results. But, while they are performing the work, they may feel the need for better understanding of their actual results.

Personal and Professional Results are the main indicators of QWL in the JDS model. In this sense, General Satisfaction with Work obtained the less favorable average score, indicating little satisfaction of workers with their work as a whole, which can be improved by further training. Satisfaction with Safety at Work also obtained a low general average score, indicating that workers have less satisfaction with factors such as employment assurance, working hours, physical environment, risks of work and safety. Satisfaction with Compensation, followed by Satisfaction with Supervision, also obtained lower general average scores. These three variables are specific satisfactions (contextual), linked to extrinsic factors and therefore, hygienic - that even being met — do not generate motivation for work. Satisfaction with the Social Environment obtained a higher overall average score and indicates that there is a good interaction among the sector's professionals.

Satisfaction with Supervision is related to Extrinsic Feedback and to the Knowledge of the Actual Results of Work. It is important to note that these three variables are interrelated, and obtained lower general average scores, indicating less satisfaction with supervision in the civil construction sector. 
The Individual Need for Growth obtained a high general average score, which represents motivational potential. When the need for growth is high, it is likely that the worker would respond positively to the task's enrichment, i.e., the tasks that offer more significance, responsibility, and knowledge of results.

With regard to the Motivational Potential of Work, Professionals and Servants had scores below 125 points, a result considered unsatisfactory and that should be better investigated.

It is possible to notice that Foremen provided very good assessments to the dimensions of Task Significance and Interrelationship, with average scores above 6.06 points, which are directly related to the Perception of Work Significance. These professionals also provided a quite well assessment for Personal and Professional Results: Satisfaction with the Social Environment, Inner Motivation to Work, Satisfaction with the Possibility of Growth, Satisfaction with Supervision, and General Satisfaction with Work. Foremen were those who provided the best assessment for the Individual Need for Growth, suggesting that a more sophisticated task and that offers more significance, responsibility and knowledge of results is very positive for the worker. It is also possible to notice that Foremen had the highest score for Motivational Potential of Work, with an average of 137.15 points, which suggests great motivational potential.

In general, all QWL variables had positive average assessments. However, for some professionals, the assessment was more negative. The most unfavorable results should be checked, and it is necessary to have a better management of factors that interfere in QWL, in order to ensure workers' satisfaction and, as a result, their best performance. These factors are: fair and adequate compensation, safe and healthy working conditions, opportunity to use and develop human capabilities, opportunity for continued growth and employment assurance, social integration and constitutionalism in the organization, work and the total space in the life of the worker, and social relevance of the work.

\section{Acknowledgements}

The authors are grateful to the National Council for Scientific and Technological Development - CNPq for the productivity research grants. They also thank FEC-UNICAMP for participating in the Program for volunteer researchers and collaborating professors.

\section{References}

Antunes, R., \& Druck, G. (2013). A terceirização como regra? [Outsourcing as a rule?] Revista TST, 79(4), 214-231. Retrieved from https://hdl.handle.net/20.500.12178/55995

Berg, J. M., Wrzesniewski, A., \& Dutton, J. E. (2010). Perceiving and responding to challenges in job crafting at different ranks: When proactivity requires adaptivity. Journal of Organizational Behavior, 31(2-3), 158-186. https://doi.org/10.1002/job.645

Camarini, G., \& CHAMON, E. M. Q. O. (2011). Qualidade de vida no trabalho: estado da arte na construção civil [Quality of work life: state of the art in civil construction]. In Chamon, E. M. Q. O. (Ed.). Qualidade de vida no trabalho [Quality of Work Life]. (pp. 1-25). Rio de Janeiro,RJ: Brasport.

Carneiro, R. S., Falcone, E., Clark, C., Del Prette, Z., \& Del Prette, A. (2007). Qualidade de vida, apoio social e depressão em idosos: relação com habilidades sociais [Quality of Life, Social Support and Depression of the Elderly: Relation with Social Abilities]. Psicologia: Reflexão e Crítica, 20(2), 229-237. https://doi.org/10.1590/S0102-79722007000200008

CBIC. (2018). Câmara Brasileira da Indústria da Construção [Brazilian Chamber of the Construction Industry]. Banco de dados - RAIS [Database - RAIS], Ministry of Labor, Brasília-DF. Retrieved November 26, 2019, from http://www.cbicdados.com.br/menu/emprego/rais-secretaria-especial-de-previdencia-e-trabalho-ministerio-da-econ omia

Clegg, C., \& Spencer, C. A. (2007). Circular and dynamic model of the process of job design. Journal of Occupational and Organizational Psychology, 80(2), 321-339. https://doi.org/10.1348/096317906X113211

Fernandes, E. C., \& Becker, J. L. (1988). Qualidade de vida no trabalho: a realidade dos CPD's [Quality of work life: the reality of CPD's]. Proceedings of the XII ANPAD Meeting. (pp. 1775-1792). Natal, Rio Grande do Norte, Brazil. https://doi.org/10.1590/1983-21172019210103

Gilgeous, V. (1998). Manufacturing managers: their quality of working life. Integrated Manufacturing Systems, 9(3), 173-181. https://doi.org/10.1108/09576069810210466

Gramkow, A. (1999). Technological innovations and quality of work life: case studies in building construction. In: $19^{\circ}$ ENEGEP, Rio de Janeiro-RJ. Proceedings.... CD ROM. https://doi.org/10.20937/atm.2018.31.01.01 
Hackman, J. R., \& Lawler, E. E. (1971). Employer reactions to job characteristics. Journal of Applied Psychology Monograph, 55(3), 259-286. https://doi.org/10.1037/h0031152

Hackman, J. R., \& Oldham, G. R. (1975). Development of the job diagnostic survey. Journal of Applied Psychology, 60(2), 159-70. https://doi.org/10.1037/h0076546

Hackman, J. R., \& Oldham, G. R. (2010). Not what it was and not what it will be: The future of job design research. Journal of Organizational Behavior, 31, 463-479. https://doi.org/10.1002/job.678

Herzberg, F. (2003). One more time: how do you motivate employees? 1968. Harvard Business Review, 81(1), 87-96. Retrieved November 26, 2019, from

http://college.emory.edu/faculty/documents/resources-chairs/One_More_Time_How_Do_You_Motivate_Employ ees.pdf

http://www.mtecbo.gov.br/cbosite/pages/home.jsf;jsessionid=vvXCPo9134ts18Lq7YcKNk6n.slave15:mte-232-cb o-01

IBGE, (2012). Instituto Brasileiro de Geografia e Estatística. [Brazilian Institute of Geography and Statistics]. Pesquisa anual da indústria da construção 2012 [Annual research of construction industry 2012], 22, 1-98. Retrieved April 21, 2019, from http://biblioteca.ibge.gov.br/visualizacao/periodicos/54/paic_2012_v22.pdf

IBGE. (2011). Instituto Brasileiro de Geografia e Estatística. [Brazilian Institute of Geography and Statistics]. Pesquisa anual da indústria da construção 2011 [Annual research of construction industry 2011], 21, 1-98. Retrieved December 13, 2014, from http://biblioteca.ibge.gov.br/visualizacao/periodicos/54/paic_2011_v21.pdf

IBGE. (2016). Instituto Brasileiro de Geografia e Estatística [Brazilian Institute of Geography and Statistics]. Pesquisa anual da indústria da construção 2016, [Annual research of construction industry 2016]. 22, 1-98. Retrieved April 21, 2019, from http://biblioteca.ibge.gov.br/visualizacao/periodicos/54/paic_2012_v22.pdf

Leite Júnior, J. A. P., Picchi, F. A., Camarini, G., \& Chamon, E. M. Q. O. (2012). Aplicabilidade de Instrumento para Avaliação da Qualidade de Vida no Trabalho em um Canteiro de Obra. [Applicability of an Instrument for Quality of Work Life Assessment in a Construction Site]. Proceedings of the XIV ENTAC, 376-384. https://doi.org/10.19070/2326-3350-130007

Lima, I. S. (1995). Qualidade de vida no trabalho na construção de edificações: avaliação do nível de satisfação dos operários de empresas de pequeno porte. [Quality of work life in building construction: assessment of satisfaction level of small business workers]. (Doctoral Dissertation, Federal University of Santa Catarina, Santa Catarina, Brazil.

Moraes, L. F. R., \& Kilimnik, Z. M. (1989). A qualidade de vida no trabalho burocrático automatizado. [Quality of life in automated bureaucratic work]. UFMG/FACE/CEPAD: CNPq Research report, Belo Horizonte-MG.

MTE. (2007). Ministério do Trabalho e Emprego. [Ministry of Labor and Employment]. Classificação Brasileira de Ocupações. [Brazilian Classification of Occupations]. Retrieved September 25, 2018, from

Okoye, P. U., Okolie, K. C., \& Aderibigbe, Y. W. (2014). Correlation of casualization mechanism and construction workers safety behavior. International Journal of Engineering and Innovative Technology - IJEIT, 3(9), 135-141. Retrieved November 26, 2019, from http://www.ijeit.com/Vol\%203/Issue\%209/IJEIT1412201403_24.pdf

Parker, S. K., \& Turner, N. (2002). Work design and individual work performance: Research findings and an agenda for future inquiry. In Sonnentag, S. (Ed.). The psychological management of individual performance: A handbook in the psychology of management in organizations. (pp. 69-93) Chichester, UK: Wiley. Retrieved November 26, 2019, from https://doi.org/10.1002/0470013419.ch4

Parker, S. K., \& Wall, T. D. (2001). Work design: Learning from the past and mapping a new terrain. In Anderson, N., Ones, D. S., Sinangil, H. K. \& Wisvesvaran, C. (Eds.). Handbook of industrial work and organizational psychology. (pp. 90-109). London, UK: Sage, v. 1. https://doi.org/10.4135/9781848608320.n6

Parker, S. K., Wall, T. D., \& Cordery, J. L. (2001). Future work design research and practice: Towards an elaborated model of work design. Journal of Occupational and Organizational Psychology, 74, 413-440. https://doi.org/10.4135/9781848608320.n6

Pedroso, B., Pilatti, L. A., Santos, C. B., \& Santos Junior, G. (2010). Potencial motivador do trabalho: tradução e adaptação cultural do instrumento de Hackman e Oldham. [Motivating potential score: translation and cultural adaptation of the Hackman and Oldham's instrument]. Revista Produção Online, 10(3), 670-697. https://doi.org/10.14488/1676-1901.v10i3.533

Resende, M. C., \& Gouveia, V. W. (2011). Qualidade de vida em adultos com deficiência física. [Quality of life in 
adults with physical disability]. Psicologia: Reflexão e Crítica, 24(1), 99-106. https://doi.org/10.1590/S0102-79722011000100012

Rodrigues, M. V. C. (2014). Qualidade de vida no trabalho: evolução e análise no nível gerencial. [Quality of work life: Evolution and analysis of management level]. (14 ${ }^{\text {th }}$.ed.) Petrópolis: Vozes.

Sant'Anna, A. S., Kilimnik, Z. M., \& Moraes, L. F. R. (2011). Antecedentes, origens e evolução do movimento em torno da qualidade de vida no trabalho. [Background, origins, and evolution of the movement around the quality of work life]. In Sant'Anna, A. S., Kilimnik, Z. (Eds.). Qualidade de vida no trabalho: abordagens e fundamentos [Quality of work life: approaches and fundamentals]. (pp. 3-30). Rio de Janeiro, RJ: Elsevier.

Silva, J., Saldanha, A. A. W., \& Azevedo, R. L. W. (2010). Variáveis de impacto na Qualidade de vida de pessoas acima dos 50 anos HIV+ [Variables of impact on quality of life of HIV-positive people over 50 years old]. Psicologia: Reflexão e Crítica, 23(1), 56-63. https://doi.org/10.1590/S0102-79722010000100008

Tolfo, S. R., \& Piccinini, V. C. (2011). Quality of work life in the best companies to work for in Brazil: mismatches between theory and practice. In Sant'Anna, A. S. \& Kilimnik, Z. M. (Eds.). Qualidade de vida no trabalho: abordagens e fundamentos [Quality of work life: approaches and fundamentals]. (pp. 85-112). Rio de Janeiro, RJ: Elsevier.

Turner, A. N., \& Lawrence, P. R. (1965). Industrial jobs and the worker An Investigation of Response to Task Attributes. Boston: Harvard Graduate School of Business Administration.

Wall, T. D., Cordery, J. L., \& Clegg, C. W. (2002). Empowerment, performance, and operational uncertainty: A theoretical integration. Applied Psychology: An International Review, 51(1), 146-169. https://doi.org/10.1111/1464-0597.00083

Walton, R. E. (1973). Quality of working life: what is it? Sloan Management Review, 15(1), 11-21.

\section{Copyrights}

Copyright for this article is retained by the author(s), with first publication rights granted to the journal.

This is an open-access article distributed under the terms and conditions of the Creative Commons Attribution license which permits unrestricted use, distribution, and reproduction in any medium, provided the original work is properly cited. 